\title{
Pathological Grade and Gender are Predictors of Small Renal Cell Carcinoma Growth
}

Koichi Sugimoto $^{1^{*}}$, Shunji Maekura ${ }^{2}$, Nobutaka Shimizu ${ }^{1}$, Ken Ochiai ${ }^{2}$, Yumiko Sekiguchi $^{3}$, Naoki Matsumura ${ }^{4}$, Taiji Hayashi ${ }^{4}$, Tsukasa Nishioka $^{4}$, Atsunobu Esa $^{5}$ and Hirotsugu Uemura ${ }^{1}$

${ }^{1}$ Department of Urology, Kinki University Faculty of Medicine, Osaka-Sayama, Osaka, Japan

${ }^{2}$ Department of Pathology, Sakai Hospital Kinki University Faculty of Medicine, Sakai, Osaka, Japan

${ }^{3}$ Department of Laboratory, Sakai Hospital Kinki University Faculty of Medicine, Sakai, Osaka, Japan

${ }^{4}$ Department of Urology, Sakai Hospital Kinki University Faculty of Medicine, Sakai, Osaka, Japan

${ }^{5}$ Department of Urology, NTT West Osaka Hospital, Osaka, Osaka, Japan

"Corresponding author: Koichi Sugimoto, M.D., Department of Urology, Kinki University Faculty of Medicine, 377-2 Ohno-Higashi, Osaka-Sayama, Osaka 589-8511, Japan, Tel: +81-72-366-0221; Fax: +81-72-365-6273; E-mail: sugimoto@sakai.med.kindai.ac.jp

Received date: October 14 2014, Accepted date: November 28 2014, Published date: December 5, 2014

Copyright: ( 2014 Sugimoto K, et al. This is an open-access article distributed under the terms of the Creative Commons Attribution License, which permits unrestricted use, distribution, and reproduction in any medium, provided the original author and source are credited.

\begin{abstract}
Objective: This study was undertaken to investigate the clinicopathological factors that influence the growth of a small renal mass (SRM) in patients subjected to a delayed surgery intervention.

Methods: We reviewed the clinical records of 37 patients with SRM $4 \mathrm{~cm}$ at diagnosis, who underwent delayed surgical intervention during surveillance from January 2000 to December 2013. Radiographic evaluation using computed tomography (CT) scan, magnetic resonance imaging (MRI) were performed at least every 6 months and the tumor size was determined at least twice.

Results: Histopathological analysis revealed that in 35 of the 37 patients the tumor was malignant in stage pT1aNOM0. There were 28 clear cell carcinomas and 7 non clear cell carcinomas. There was a significant difference in the time to tumor doubling (TTD) among clear cell carcinomas $(p=0.033)$. There was also a significant difference in the tumor growth rate (mm/year) of clear cell carcinomas between male and female patients $(p=0.028)$.

Conclusion: The growth rate of small renal mass was slow in the majority of our patients. Pathological grade and gender significantly influenced the growth of clear cell carcinomas.
\end{abstract}

Keywords: Renal cell carcinoma; Small renal mass; Growth factor; Natural history

\section{Introduction}

Renal cell carcinoma (RCC) detection was performed using noninvasive abdominal imaging techniques, which included: ultrasonography (US), computed tomography (CT) and magnetic resonance imaging (MRI) [1-5].

Following a retrospective review, it was found that most small renal masses (SRMs) showed a slow growth rate and low malignant potential [6]. In a previous study, we found that the growth factor of SRMs was highly associated with their pathological grade [7].

In this study, we investigated growth factors in a larger sample size, using the enzyme mindbomb E3 ubiquitin protein ligase 1 (MIB-1), which is strongly associated with pathological grade.

\section{Methods}

Thirty-four patients with 37 incidentally detected SRMs $4 \mathrm{~cm}$ were retrospectively reviewed at three centers from January 2000 to December 2013. All the patients were operated on soon after we noted the tumor had become larger. They underwent at least two CT scans prior to surgical intervention. None of the patients underwent renal biopsy for a diagnosis. The pathological results confirmed the diagnosis of clear cell carcinoma for 28 of the 37 patients. We conducted the following analyses in the 28 patients to study the relationship between the growth rate of clear cell carcinoma and various factors.

The maximum tumor diameter and tumor volume were calculated at two points using images yielded by the same diagnostic modality. Tumor volume (V) was calculated using the following equation, assuming the tumor had a spherical form [8].

$$
\mathrm{V}=\{4 / 3 \times \pi \times \mathrm{a} \times \mathrm{b} \times(\mathrm{a}+\mathrm{b} / 2)\} \times 1 / 8
$$

where $\mathrm{a}$ indicates the maximum tumor diameter and $\mathrm{b}$ denotes the minimum tumor diameter.

The time to tumor doubling (TTD) was calculated using the following equation $[9,10]$.

$$
\mathrm{DT}=(\mathrm{T}-\mathrm{T} 0) \times \log 2 / \log \mathrm{V}-\log \mathrm{V} 0
$$

where T-T0 indicates the interval between time two measurements and $\mathrm{V} 0$ and $\mathrm{V}$ denote the tumor volume at $\mathrm{T} 0$ and $\mathrm{T}$, respectively.

MIB-1 Immunohistochemical Assay: Detailed descriptive methodology has previously been published [11]. 
Citation: Sugimoto K, Maekura S, Shimizu N, Ochiai K, Sekiguchi Y, et al (2014) Pathological Grade and Gender are Predictors of Small Renal

Page 2 of 4

Immunohistochemistry against the Ki-67 antigen was performed using a monoclonal MIB-1 antibody (clone MIB-1, mouse IgG1, 1:100) followed by a biotin goat antibody $(1: 100)$ for 30 minutes at room temperature. The slides were rinsed in tris phosphate buffered saline $(\mathrm{pH}$ 7.6) between each step. Visualization of staining utilized a 3amino-9-ethylcarbazole solution. Finally, the sections were slightly counterstained in Mayer's hematoxylin.

Quantitation of Immunoreactivity: Owing to heterogeneous content of proliferative tumor cells in the tumors, areas of highest proliferative activity (hot spots) were found by scanning the tumor sections at low magnification $(40 \times$ and $100 \times)$. Within these hot spots, the tumor cell counts were performed by a random sampling technique at $400 \times(10 \times$ ocular and $40 \times$ objective $)$ using a $10 \times 10$ grid contained within the eyepiece. MIB-1 score represented the number of stained tumor cell nuclei counted.

Clinical and pathological stages determination incorporated the 2009 American Joint Committee on Cancer / International Union Against Cancer TNM guidelines [12]. Clinical and pathological characteristics with potential association to tumor growth rate and stage were investigated. After surgery, follow-ups were conducted with patients every 3-6 months. Hemodialysis patients were not included in this study because patients on dialysis were at great risk of developing RCC, due to end-stage renal disease, than healthy controls of equivalent age [13-15].

Statistically significant data was compared using the nonparametric Mann-Whitney U-test. The risk of prognostic factors was assessed using both logistic regression analysis as well as the Cox proportional hazards regression model, respectively. A level of $\mathrm{P}<0.05$ was accepted as the statistical significance.

\section{Results}

The mean age of the patients was 64.8 years (range: $35-80$ ). There were 29 men and 8 women. In all patients, the tumors were $\leq 4 \mathrm{~cm}$ at diagnosis. Histopathological analysis revealed that 35 of the 37 patients were malignant in pT1aN0M0. The pathological results are presented in Table 1.

\begin{tabular}{|l|l|}
\hline Age & $64.8(35-80)$ \\
\hline Sex(Male/Female) & $29 / 8$ \\
\hline Histologic Subtype & \\
\hline Clear cell Carcinoma & 28 \\
\hline Papillary cell Carcinome & 6 \\
\hline Multilocular Clear cell & 1 \\
\hline Oncocytoma & 2 \\
\hline
\end{tabular}

Table 1: Patients characteristics

We closely monitored the 28 patients with clear cell carcinomas. Sixteen of those tumors (57.1\%) were of pathological grade 1, eleven (39.3\%) were grade 2 and one (3.6\%) was grade 3. In addition, seven tumors (25\%) were of pathological Fuhrman grade 1, nineteen (67.9\%) were of pathological Fuhrman grade 2 and two (7.1\%) were of pathological Fuhrman grade 3. There were 22 men and 6 women. Three tumors were MIB- 1 score $>5 \%$ and 25 were MIB- 1 score $<5 \%$ (Figure 1).

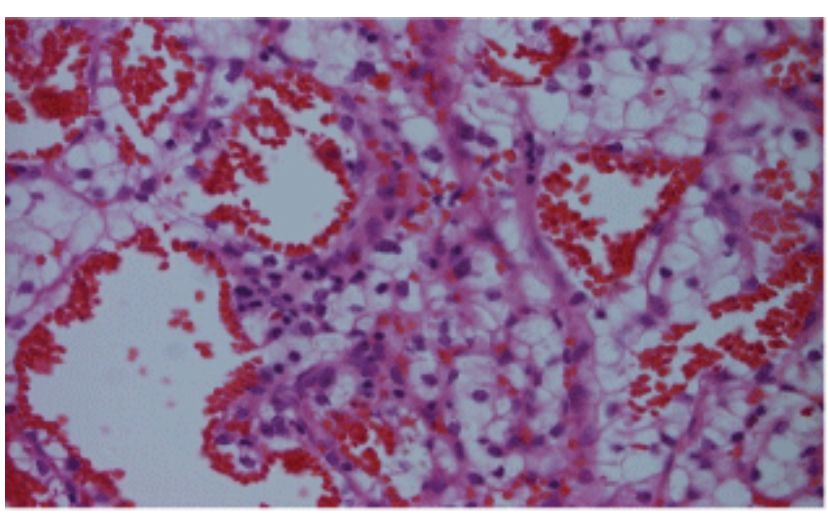

(a)

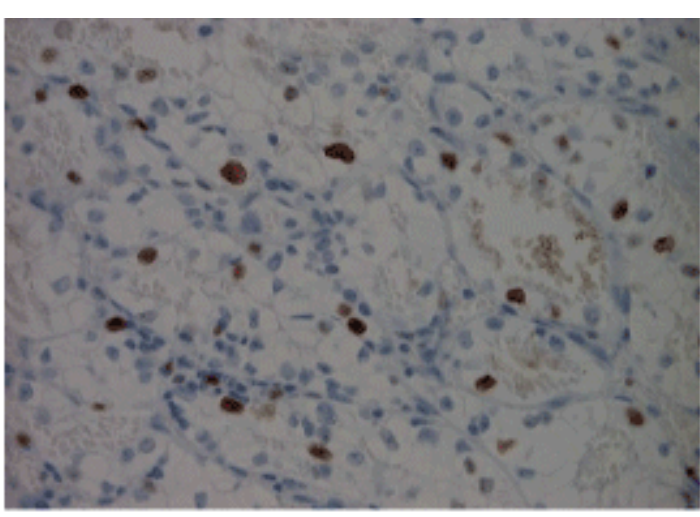

(b)

Figure 1a and b: Pathological finding of clear cell carcinoma, Hematoxylin-Eosin stain $(\times 40)$ MIB-1 index $>5(\times 40)$.

As shown in Table 2, there were significant differences in TTD between tumors of pathological grade 1 and those of grade 2 , or 3 , as well as in tumor diameter ( $\mathrm{mm} /$ year) men and women. In contrast, multivariate analysis showed no significant difference in TTD or tumor diameter by each factor.

\section{Discussion}

Recently, incidental detection of small, asymptomatic renal tumors has been on the rise. The good prognosis of incidental RCC is excellent, as evidenced by the results of surgery [16,17]. The gender ratio is approximately $2: 1$, male to female, respectively [18]. Cigarette smoking, obesity and hypertension have been implicated as risk factors although the increase in risk is relatively modest [19]. The etiology of most RCCs remains unclear.

In general, size is proportionate to the grade of malignancy [20]. The questions raised become: "When should tumors be treated proactively?" and "How big in diameter?" In the case of SRM smaller than $1.0 \mathrm{~cm}, 38-46 \%$ are benign. On the other hand, only $6.3-7.1 \%$ are 
Citation: Sugimoto K, Maekura S, Shimizu N, Ochiai K, Sekiguchi Y, et al (2014) Pathological Grade and Gender are Predictors of Small Renal

Page 3 of 4

benign for lesions larger than $7.0 \mathrm{~cm}$ in diameter [21]. It has been reported that renal masses $3 \mathrm{~cm}$ in diameter have a more aggressive potential, resulting in more incidences of metastases [22,23] (Tables 2 and 3).

\begin{tabular}{|c|c|c|c|c|c|}
\hline \multicolumn{2}{|l|}{ Variables } & \multicolumn{2}{|l|}{ Univariate } & \multicolumn{2}{|l|}{ Multivariate } \\
\hline & & & & $\mathrm{HR}(95 \% \mathrm{Cl})$ & \\
\hline Factor & TTD & & $P$ value & & $P$ value \\
\hline Grade & $\begin{array}{l}\text { Grade1 } \\
27.9+4.08(n=16)\end{array}$ & $\begin{array}{l}\text { Grade2,3 } \\
17.7+4.06(n=12)\end{array}$ & 0.033 & $0.193(0.028-1.321)$ & 0.094 \\
\hline Gender & $\begin{array}{l}\text { Male } \\
24.23+3.52(n=22)\end{array}$ & $\begin{array}{l}\text { Female } \\
20.9+6.09(n=6)\end{array}$ & N.S & & \\
\hline Age & $\begin{array}{l}<70 \\
25.37+4.05(n=16)\end{array}$ & $\begin{array}{l}>70 \\
21.05+4.60(n=12)\end{array}$ & N.S & & \\
\hline Furman Grade & $\begin{array}{l}\text { Grade } 1 \\
27.3+6.90(n=7)\end{array}$ & $\begin{array}{l}\text { Grade } 2,3,4 \\
22.26+3.36(n=21)\end{array}$ & N.S & & \\
\hline Furman Grade2 & $\begin{array}{l}\text { Grade } 1,2 \\
24 \cdot 30+3 \cdot 19(n=26)\end{array}$ & $\begin{array}{l}\text { Grade } 3,4 \\
13.30+5.00(n=2)\end{array}$ & N.S & & \\
\hline MIB-1 & $\begin{array}{l}>5 \% \\
17.50+5.94(\mathrm{n}=3)\end{array}$ & $\begin{array}{l}<5 \% \\
24.24+3.30(n=25)\end{array}$ & N.S & & \\
\hline
\end{tabular}

Table 2: Intergroup comparison of TTD according to each factor

\begin{tabular}{|c|c|c|c|c|c|}
\hline \multicolumn{2}{|l|}{ Variables } & \multicolumn{2}{|l|}{ Univariate } & \multicolumn{2}{|l|}{ Multivariate } \\
\hline & & & & $\mathrm{HR}(95 \% \mathrm{Cl})$ & \\
\hline Factor & $\mathrm{mm} /$ year & & $P$ value & & $P$ value \\
\hline Grade & $\begin{array}{l}\text { Grade1 } \\
4.32 \pm 1.07(n=16)\end{array}$ & $\begin{array}{l}\text { Grade2,3 } \\
3.88 \pm 0.91(n=12)\end{array}$ & N.S & & \\
\hline Gender & $\begin{array}{l}\text { Male } \\
4.75 \pm 0.86(n=22)\end{array}$ & $\begin{array}{l}\text { Female } \\
1.84 \pm 0.47(n=6)\end{array}$ & 0.028 & $0.309(0.035-2.717)$ & 0.289 \\
\hline Age & $\begin{array}{l}<70 \\
3.08 \pm 0.48(n=16)\end{array}$ & $\begin{array}{l}>70 \\
5.53 \pm 1.49(n=12)\end{array}$ & N.S & & \\
\hline Furman Grade & $\begin{array}{l}\text { Grade } 1 \\
3.06 \pm 0.73(n=7)\end{array}$ & $\begin{array}{l}\text { Grade } 2,3,4 \\
4.49 \pm 0.92(n=21)\end{array}$ & N.S & & \\
\hline Furman Grade2 & $\begin{array}{l}\text { Grade } 1,2 \\
4.00 \pm 0.76(n=26)\end{array}$ & $\begin{array}{l}\text { Grade } 3,4 \\
5.81 \pm 0.57(n=2)\end{array}$ & N.S & & \\
\hline MIB-1 & $\begin{array}{l}>5 \% \\
3.52 \pm 0.91(n=3)\end{array}$ & $\begin{array}{l}<5 \% \\
4.20 \pm 0.80(n=25)\end{array}$ & N.S & & \\
\hline
\end{tabular}

Table 3: Intergroup comparison of tumor diameter ( $\mathrm{mm} /$ year) according to each factor

Moreover, the proliferation rate should also be considered. Renal masses $<2.45 \mathrm{~cm}$ at diagnosis were associated with an average growth rate of $0.13 \mathrm{~cm} /$ year, while masses $>2.45 \mathrm{~cm}$ had a growth rate of 0.40 $\mathrm{cm} /$ year [24]. Following the diagnosis and conclusion of the observation, larger tumors and larger tumor volumes tended to progress. Significant differences in both the average growth rate $(0.80$ $\mathrm{cm} /$ year vs. $0.3 \mathrm{~cm} /$ year $)$ and the average volumetric growth rate $(27.1$ $\mathrm{cm}^{3} /$ year vs. $6.2 \mathrm{~cm}^{3} /$ year) have also been observed [25].
Previously when dealing with early prostate cancer, active surveillance was often considered. However, recent advances with respect to tumor detection tools, such as ultrasound and high speed CT scanning, have made for the possibility of RCC surveillance [26-30]. Active surveillance is increasing in frequency, especially with elderly patients or patients with comorbidities who may not be viable surgery candidates. This approach is based on retrospective cohort study of the growth rate and natural history of incidentally detected small renal tumors [29-31]. 
In our previous study, the only indicator of the growth rate of RCC $(p=0.068)$ found was the pathological grade [7]. In order to explore some other parameters, we investigated proliferation, which is strongly associated with the pathological grade, as an index. Proliferative indices based upon various markers have been correlated with the outcome of clear cell RCC (Ki-67 et al.) [32]. However contrary to this correlation, our study revealed that the MIB-1 of proliferation was not a marker of RCC growth.

Another study suggested the RENAL nephrectomy score was associated with the annual growth rate of renal masses [33]. Although we did not study the RENAL nephrectomy score, this can be considered as one of the growth factors.

The results of the present study confirmed that the pathological grade $(p=0.033)$ was a strong predictor of growth rate. In addition, gender $(\mathrm{p}=0.028)$ was also found to be significantly associated with proliferation. This may facilitate the determination of patients with SRMs that should be actively monitored in the event that delaying surgical treatment is desirable.

\section{Conclusions}

In conclusions, the growth rate of small renal mass was slow in the majority of our patients. The pathological grade and gender were found to significantly influence the growth of clear cell carcinomas.

\section{Acknowledgments}

This study was supported by a grant from the Osaka Kidney Foundation (OKF). (Grant No. OKF14-0013).

\section{References}

1. Wunderlich H, Schumann S, Jantitzky V, Moravek P, Podhola M, et al (1998) Increase of renal cell carcinoma incidence in central Europe. Eur Urol 33: 538-541.

2. Chow WH Devesa SS, Warren JL, Fraumeni JF Jr (1999) Rising incidence of renal cell cancer in the United States. JAMA 281: 1628-1631.

3. Hock LM, Lynch J, Balaji KC (2002) Increasing incidence of all stages of kidney cancer in the last 2 decades in the United States: an analysis of surveillance, epidemiology and end results program data. J Urol 167: 57-60.

4. Lightfoot N, Conlon M, Kreiger N, Bissett R, Desai M, et al. (2000) Impact of noninvasive imaging on increased incidental detection of renal cell carcinoma. Eur Urol 37: 521-527.

5. Siemer S, Uder M, Humke U, Lindenmeier T, Moll V, et al. (2000) [Value of ultrasound in early diagnosis of renal cell carcinoma]. Urologe A 39: 149-153.

6. Chawla SN, Crispen PL, Hanlon AL, Greenberg RE, Chen DY, et al (2006) The natural history of observed enhancing renal masses: metaanalysis and review of the world literature. J Urol 175: 425-431.

7. Sugimoto K, Shimizu N, Oki T, Nose K, Nishioka T, et al. (2013) Clinical outcome of incidentally discovered small renal cell carcinoma after delayed surgery. Cancer Manag Res 5: 85-89.

8. Ozono S, Miyao N, Igarashi T, Marumo K, Nakazawa H, et al. (2004) Tumor doubling time of renal cell carcinoma measured by CT: collaboration of Japanese Society of Renal Cancer. Jpn J Clin Oncol 34: 82-85.

9. Schwartz M (1961) A biomathematical approach to clinical tumor growth. Cancer 14: 1272-1294.

10. Lindell RM, Hartman TE, Swensen SJ, Jett JR, Midthun DE, et al. (2007) Five-year lung cancer screening experience: $\mathrm{CT}$ appearance, growth rate, location, and histologic features of 61 lung cancers. Radiology 242: 555-562.

11. Cattoretti G, Becker MH, Key G, Duchrow M, Schluter C, et al. (1992) Monoclonal antibodies against recombinant parts of the Ki-67 antigen
(MIB-1 and MIB-3) detect proliferating cells in microwave-processed formalin-fixed paraffin sections. J Pathol 168: 357-363.

12. Sobin LH, Gospodarowicz MK, Wittekind Ch (2009) TMN Classification of malignant tumours 7 th editon, Wiley-Blackwell.

13. Vamvakas S, Bahner U, Heidland A (1998) Cancer in end-stage renal disease: potential factors involved -editorial-. Am J Nephrol 18: 89-95.

14. Choyke PL (2000) Acquired cystic kidney disease. Eur Radiol 10: 1716-1721.

15. Hora M, Hes O, Reischig T, Urge T, Klecka J, et al. (2008) Tumours in end-stage kidney. Transplant Proc 40: 3354-3358.

16. Hafez KS, Fergany AF, Novick AC (1999) Nephron sparing surgery for localized renal cell carcinoma: impact of tumor size on patient survival, tumor recurrence and TNM staging. J Urol 162: 1930-1933.

17. Kunkle DA, Egleston BL, Uzzo RG (2008) Excise, ablate or observe: the small renal mass dilemma--a meta-analysis and review. J Urol 179: 1227-1233.

18. Decastro GJ, McKiernan JM (2008) Epidemiology, clinical staging, and presentation of renal cell carcinoma. Urol Clin North Am 35: 581-592.

19. Dhôte R, Pellicer-Coeuret M, Thiounn N, Debré B, Vidal-Trecan G (2000) Risk factors for adult renal cell carcinoma: a systematic review and implications for prevention. BJU Int 86: 20-27.

20. Schlomer B, Figenshau RS, Yan Y, Venkatesh R, Bhayani SB (2006) Pathological features of renal neoplasms classified by size and symptomatology. J Urol 176: 1317-1320.

21. Frank I, Blute ML, Cheville JC, Lohse CM, Weaver AL, et al. (2003) Solid renal tumors: an analysis of pathological features related to tumor size. J Urol 170: 2217-2220.

22. Remzi M, Ozsoy M, Klingler HC, Susani M, Waldert M, et al. (2006) Are small renal tumors harmless? Analysis of histopathological features according to tumors $4 \mathrm{~cm}$ or less in diameter. J Urol 176: 896-899.

23. Lane BR, Tobert CM, Riedinger CB (2012) Growth kinetics and active surveillance for small renal masses. Curr Opin Urol 22: 353-359.

24. Mason RJ, Abdolell M, Trottier G, Pringle C, Lawen JG, et al. (2011) Growth kinetics of renal masses: analysis of a prospective cohort of patients undergoing active surveillance. Eur Urol 59: 863-867.

25. Smaldone MC, Kutikov A, Egleston BL, Canter DJ, Viterbo R, et al. (2012) Small renal masses progressing to metastases under active surveillance: a systematic review and pooled analysis. Cancer 118: 997-1006.

26. Crispen PL, Wong YN, Greenberg RE, Chen DY, Uzzo RG (2008) Predicting growth of solid renal masses under active surveillance. Urol Oncol 26: 555-559.

27. Kunkle DA, Crispen PL, Chen DY, Greenberg RE, Uzzo RG (2007) Enhancing renal masses with zero net growth during active surveillance. J Urol 177: 849-853.

28. Heuer R, Gill IS, Guazzoni G, Kirkali Z, Marberger M, et al. (2010) A critical analysis of the actual role of minimally invasive surgery and active surveillance for kidney cancer. Eur Urol 57: 223-232.

29. Jewett MA, Mattar K, Basiuk J, Morash CG, Pautler SE, et al. (2011) Active surveillance of small renal masses: progression patterns of early stage kidney cancer. Eur Urol 60: 39-44.

30. Mason RJ, Abdolell M, Trottier G, Pringle C, Lawen JG, et al. (2011) Growth kinetics of renal masses: analysis of a prospective cohort of patients undergoing active surveillance. Eur Urol 59: 863-867.

31. Kim SP, Thompson RH (2012) Approach to the small renal mass: to treat or not to treat. Urol Clin North Am 39: 171-179, vi.

32. Delahunt B, Bethwaite PB, Nacey JN (2007) Outcome prediction for renal cell carcinoma: evaluation of prognostic factors for tumours divided according to histological subtype. Pathology 39: 459-465.

33. Matsumoto R, Abe T, Shinohara N, Murai S, Maruyama S, et al. (2014) RENAL nephrometry score is a predictive factor for the annual growth rate of renal mass. Int J Urol 21: 549-552. 